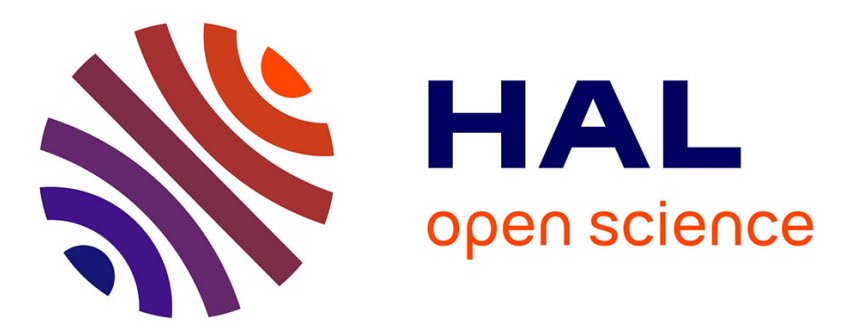

\title{
New data on bats from Dire Dawa, eastern Ethiopia, with the first record of Rhinopoma microphyllum in the country
}

Petr Benda, Mohammed Kasso, Violaine Nicolas, Pleurdeau David, Emmanuelle Stoetzel, Workalemahu Bekele Sime, Afework Bekele, Christiane C. Denys

\section{To cite this version:}

Petr Benda, Mohammed Kasso, Violaine Nicolas, Pleurdeau David, Emmanuelle Stoetzel, et al.. New data on bats from Dire Dawa, eastern Ethiopia, with the first record of Rhinopoma microphyllum in the country. Journal of Natural History, 2019, 53 (41-42), pp.2579-2591. 10.1080/00222933.2019.1705416. hal-02403472

\section{HAL Id: hal-02403472 \\ https://hal.science/hal-02403472}

Submitted on 2 Mar 2020

HAL is a multi-disciplinary open access archive for the deposit and dissemination of scientific research documents, whether they are published or not. The documents may come from teaching and research institutions in France or abroad, or from public or private research centers.
L'archive ouverte pluridisciplinaire HAL, est destinée au dépôt et à la diffusion de documents scientifiques de niveau recherche, publiés ou non, émanant des établissements d'enseignement et de recherche français ou étrangers, des laboratoires publics ou privés. 


\title{
New data on bats from Dire Dawa region, eastern Ethiopia, with the first record of Rhinopoma microphyllum in the country
}

Benda P. ${ }^{1,2}$, Kasso M. ${ }^{3}$, Nicolas V., ${ }^{4}$ Pleurdeau D. ${ }^{5}$, Stoetzel E. ${ }^{5}$, Workalemahu Bekele S. ${ }^{6}$, Bekele A. ${ }^{7}$, Denys C. ${ }^{4}$

${ }^{1}$ Department of Zoology, National Museum (Natural History), Václavské nám. 68, CZ-115 79 Praha 1, Czech Republic; email: petr_benda@nm.cz

${ }^{2}$ Department of Zoology, Faculty of Science, Charles University in Prague, Viničná 7, CZ-128 44 Praha 2, Czech Republic

${ }^{3}$ Department of Biology, College of Natural and Computational Sciences, Dire Dawa University, Dire Dawa, Ethiopia (muhesofi@yahoo.com)

${ }^{4}$ Institut de Systématique, Evolution, Biodiversité (ISYEB) UMR 7205, Muséum National d'Histoire Naturelle, CNRS, Sorbonne Universités, EPHE, Université des Antilles, Paris, France (violaine.colin@mnhn.fr, denys@mnhn.fr)

${ }^{5}$ Histoire Naturelle de l'Homme Préhistorique (HNHP) UMR 7194, Muséum National d'Histoire Naturelle, CNRS, Sorbonne Universités, UPVD, Paris, France (david.pleurdeau@mnhn.fr, stoetzel@mnhn.fr)

${ }^{6}$ College of Health Science, CHAMPS Project, Haramaya University, Harar, Ethiopia (workubeza2012@gmail.com)

${ }^{7}$ Department of Zoological Sciences, College of Natural and Computational Sciences, Addis Ababa University, Addis Ababa, Ethiopia (afeworksimegn@gmail.com)

\begin{abstract}
A small collection of bats composed of six species from Dire Dawa area, eastern Ethiopia, is presented. Besides three species previously known in the region, Rousettus aegyptiacus, Epomophorus minimus and Chaerephon pumilus, three bats were newly documented from the area, Rhinopoma microphyllum, $R$. cystops and Scotophilus leucogaster. R. microphyllum is here reported for the first time in Ethiopia. From molecular genetic comparisons Ethiopian $R$. cystops belongs to the Arabian subspecies lineage $R$. c. arabium, previously unknown from the African continent, raising interesting biogeographic questions.
\end{abstract}

Key-words. Bats, Afro-tropics, Horn of Africa.

\section{Introduction}

Global change is threatening biodiversity of the whole planet, including small mammals. At the same time biodiversity inventories of all biodiversity hotspots have yet to be completed. Thanks to the development of integrative taxonomy, the combination of molecular genetic and morphologic evidences of inventoried species leads to more precise knowledge of diversity, including cryptic species, as well as better appreciation of the biogeographic affinities of particular populations. This remains particularly valid for the mammals of the Horn of Africa including bats (see e.g. Hulva et al. 2007, Benda et al. 2015, 2016, Lanza et al. 2015, Bray and Benda 2016, Kruskop et al. 2016, Vallo et al. 2019, etc.).

Dire Dawa is a town and a federal state of the same name situated in the eastern part of Ethiopia, on the northern slope of the Chercher Mountains (Fig. 1). This range is the easternmost extension of the Ethiopian Highlands and although it extends at several places up to an altitude of $3000 \mathrm{~m}$ a. s. 1., the Dire Dawa area is situated roughly at 1100-1400 m a. s. 1. It lies in the transition between the zones of the dry evergreen Afromontane forests of the high parts of the Chercher Mountains and the dry Acacia scrublands of the arid Afar lowlands (Friis et al. 2011). From this eastern part of Ethiopia, only a small number of bat records is available. Moreover, these were collected around fifty years ago, or even earlier (see Largen et al. 1974), and only few records were made recently in the broader region (Table 1; Lavrenchenko et al. 2004, 2010). On the other hand, the diversity of bats in Ethiopia is relatively well studied; the list of bats of the country comprises at least 80 species (Lavrenchenko et al. 2004, 2010, Kruskop et al. 2016, Vallo et al. 2019) with at least two endemics, Myotis scotti Thomas, 1927 and Plecotus balensis Kruskop et Lavrenchenko, 2000 (Lavrenchenko and Afework Bekele 2017). However, most of bat records in Ethiopia were made in the western part of the country, as shown by the reviews by Largen et al. (1974), Yalden et al. (1996), and Lavrenchenko et al. (2004). Here, we bring new morphological and molecular data on bats from the Dire Dawa area, a corner of Ethiopia that has been, and continues to be, neglected and 
understudied by bat researchers. This inventory will allow us to provide some biogeographic conclusions about the bats of this region.

\section{Material and Methods}

We conducted field work in the Dire Dawa area between $17^{\text {th }}$ and $29^{\text {th }}$ of November of 2017. Bat sampling was carried out in caves, bush and scrub forest, horticultural crops farmland, warehouses and close to human dwellings and pond and streams. Four to six mist-nets $(9 \mathrm{~m} \times 2 \mathrm{~m}, 12 \mathrm{~m} \times 6 \mathrm{~m}$ and $8 \mathrm{~m} \times 3 \mathrm{~m})$ were set between the time period of 18:45 h and 22:00 $\mathrm{h}$ and checked at an interval of 15-20 minutes. Bats were sampled at several sites (Dire Dawa, Toni Farm, Enkuftu

Cave, Goda Buticha Cave, Lege Hare river or stream and different ponds in Genda Gebere farm) using either erected or mobile mistnets. Visual observations and acoustic recordings were also conducted in situ at dusk and at night during trappings with the aid of torches. Daytime roosting site inspection was also conducted. The captured bats were carefully removed from the mistnet, placed in individual cotton bags, identified and measured. From each species, whenever captured representative sub-adults or adults individuals from both sexes were euthanised following ethic rules for morphometric analysis whereas the remaining were released on site after species identification and measurements have been taken Muscletissue samples and non-lethal $3 \mathrm{~mm}$ wing biopsy samples were taken from the euthanized and the released specimens, respectively, and placed in 95\% ethanol for molecular analyzes. Standard external dimensions (head and body length, tail length, forearm length, ear length) were taken with an accuracy to $1.0 \mathrm{~mm}$, and $0.01 \mathrm{~mm}$ for skull dimensions (5-6 dimensions, see below). Skulls were extracted from only a part of the specimens and were deposited in the reference collection of the National Museum of Ethiopia (Addis Ababa).

The ethanol-preserved tissue samples from both collected Rhinopoma specimens were used for a molecular genetic comparison. The DNA was extracted from the samples using the NucleoSpin Tissue Core kit (Macherey-Nagel, Hoerdt, France). The Cytb gene was amplified using PCR primers L14723 (CCAATGACATGAAAAATCATCGTT), and H15915 (TCTCCATTTCTGGTTTACAAGAC; Ducroz et al. 2001). The PCR consisted of a first denaturation at $94 \mathrm{C}$ for $3 \mathrm{~min}$, followed by 35 cycles $\left(30 \mathrm{~s}\right.$ at $94^{\circ} \mathrm{C}, 40 \mathrm{~s}$ at $52 \mathrm{C}$ and $90 \mathrm{~s}$ at $72^{\circ} \mathrm{C}$ ), and a final extension for $5 \mathrm{~min}$ at $72 \mathrm{C}$. The doublestranded PCR products were purified and sequenced at the Eurofins genomics laboratory (France).

For the phylogenetic reconstruction we used a Bayesian analysis because it has several advantages over other methods of phylogenetic inference, including easy interpretation of results, the ability to incorporate prior information and some computational advantages (see Larget and Simon 1999). We included in our analysis our two sequences from Ethiopia and all reference sequences previously used by Benda et al. (2012a; see Appendix). The new and reference sequences were 1140 bp long. In the GenBank database numerous other sequences are available, but they are much shorter (317-402 bp). These short segments were not included in our analysis except for five sequences coming from areas not represented in the above dataset (Hulva et al. 2007, Levin et al. 2008, Memish et al. 2013; see Appendix). Bayesian analysis was conducted using MrBayes v. 3.2.5 (Ronquist and Huelsenbeck 2003), with two runs and four chains (three hot and one cold), each of 20,000,000 generations, with trees sampled every 100 generations. Stationarity was assessed by examining the average SD of split frequencies and the potential scale reduction factor. After a visual inspection, the first $25 \%$ of iterations were excluded as burn-in time and the resulting trees were combined in a majority rule consensus tree to obtain posterior probabilities. The most appropriate model of sequence evolution was assessed using the Akaike information criterion (Akaike 1973) test as implemented in MrModeltest v.3.7 (Posada and Crandall 2001) using MrMTgui (available from http://genedrift.org/software/mrmtgui.html). The GTR + I + G models were retained. To root our tree, we included a sequence of Asellia tridens (GenBank JF439010).

\section{Annotated list of species}

\section{Roussettus aegyptiacus (Geoffroy, 1810) - Egyptian rousette}

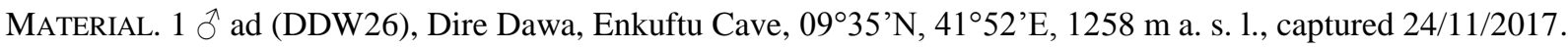


One male of the Egyptian rousette was caught at the Enkuftu Cave within the Dire Dawa town. A huge colony of this bat was observed roosting during day time in this cave. This locality, together with Harar from where this bat was reported by Hayman and Hill (1971), constitutes the north-eastern limit of the known species range in sub-Saharan Africa (Bergmans 1994). The new record also represents the northernmost record of $R$. aegyptiacus from Ethiopia, since the known distribution of this bat in the country has been confined to the territory south of the $9^{\circ} 20^{\prime} \mathrm{N}$ (in the western part of the country, the northernmost locality is the Geda Gilinde Cave at $9^{\circ} 12^{\prime}$ N; Stríbná et al. 2019). The region of Dire Dawa probably also constitutes the northernmost area of the species occurrence in the eastern part of Africa, i.e. nominally assigned to be inhabited by $R$. a. leachii (Smith, 1829), see Bergmans (1994). The only east-African finding originating from an area more to the north, Addi Sciaddi [= Addisc Addi; $15^{\circ} 40^{\prime} \mathrm{N}, 38^{\circ} 37^{\prime} \mathrm{E}$ ] in Eritrea (Sordelli 1902), was doubted by Bergmans (1994), although it was accepted by Senna (1905), Largen et al. (1974) and Happold (2013a). Without doubt, Dire Dawa area represents an extreme and outlying distributional occurrence spot of R. aegyptiacus in tropical Africa.

Dimensions of the collected specimen are as follows: weight $110 \mathrm{~g}$, head and body length $140 \mathrm{~mm}$, forearm length $90 \mathrm{~mm}$, ear length $22 \mathrm{~mm}$, largest skull length $42.67 \mathrm{~mm}$, condylobasal length $40.48 \mathrm{~mm}$, zygomatic width $25.97 \mathrm{~mm}$, neurocranium width $17.88 \mathrm{~mm}$, neurocranium height $13.46 \mathrm{~mm}$, length of upper tooth-row $16.03 \mathrm{~mm}$. These data fall into the middle of the ranges of $R$. a. leachii from eastern Africa ( $n=72$; Bergmans 1994), while some of them exceed the upper limits of the ranges of $R$. a. arabicus Anderson, 1902 from the southern part of the Middle East (n=58; Benda et al. 2012b). The latter subspecies was suggested to occur in eastern Ethiopia (Harar) by Hayman and Hill (1971) and Largen et al. (1974). However, our record supports the view by Bergmans (1994), who considered the presence of small-sized $R$. $a$. arabicus in eastern Ethiopia as improbable and all the populations of this bat from the eastern part of sub-Saharan Africa referred solely to large-sized $R$. a. leachii.

\section{Epomophorus minimus Claessen et De Vree, 1991 - Least epauletted fruit bat}

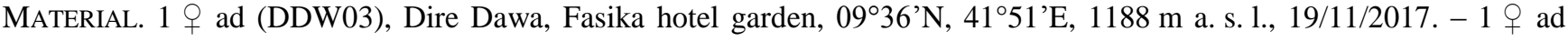
(DDW18), Dire Dawa, Toni Farm (Dire Dawa University), 09³7’N, 4150’E, 1156 m a. s. 1., 19/11/2017.

Two females of the least epauletted fruit bat were caught at two sites within the Dire Dawa town. According to data by Claessen and De Vree (1991), the records from Dire Dawa area only slightly shift the known limits of the distribution range of this species to the north-east. In the surrounding areas of the eastern edge of the Chercher Mountains, E. minimus represents a regularly encountered fruit bat species; specimens were collected in the areas some 50-80 km south-east of Dire Dawa, at Harar, Errer Valley, and Babille (Claessen and De Vree 1991, Lavrenchenko et al. 2010); Bahadu, the type locality of E. minimus, lies only some $145 \mathrm{~km}$ WNW of Dire Dawa.

External dimensions of the specimens collected in Dire Dawa are as follows (DDW03/DDW18): weight 36/38 g, head and body length $95 / 109 \mathrm{~mm}$, forearm length $60 / 65 \mathrm{~mm}$, ear length $16 / 19 \mathrm{~mm}$; skull dimensions (DDW03): largest skull length $31.12 \mathrm{~mm}$, condylobasal length $29.86 \mathrm{~mm}$, zygomatic width $17.98 \mathrm{~mm}$, neurocranium width $12.96 \mathrm{~mm}$, neurocranium height $9.81 \mathrm{~mm}$, length of upper tooth-row $10.89 \mathrm{~mm}$. The species identification based on the craniodental data comparison conforms to those given by Claessen and De Vree (1991: 219); the result of discriminant function counted from three cranial measurements is 47.5. In E. minimus this value should be below 116, while higher values indicate $E$. labiatus (Temminck, 1837), which, however, is not known to occur in eastern Ethiopia or in Somalia (Claessen and De Vree 1991, Lanza et al. 2015).

\section{Rhinopoma microphyllum (Brünnich, 1782) - Greater mouse-tailed bat}

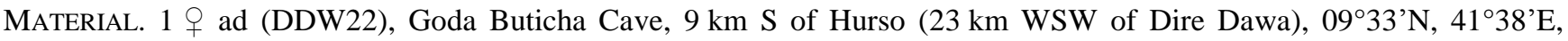
1382 m a. s. 1., 23/11/2017.

An adult female of the greater mouse-tailed bat was found inside the Goda Buticha Cave. The surroundings of the cave are composed of dry scrubland with rocky cliffs, and a small village with some cultivations is found near the cave. The environment thus corresponds well with the known ecological requirements of this bat (see, e.g. Schlitter and Qumsiyeh 
1996). This finding represents the first record of R. microphyllum in Ethiopia and also a range extension of the south-eastern limit of the known distribution of the species in Africa (Van Cakenberge and De Vree 1994, Schlitter and Qumsiyeh 1996, Aulagnier 2013b). This bat is known from Sudan and Djibouti, but not Somalia (Koopman 1975, Pearch et al. 2001, Lanza et al. 2015). In Sudan, it was recorded southernmost in southern Kordofan (Jebel Talao, $2 \mathrm{~km}$ NE of Kaduqli, $11^{\circ} 02^{\prime} \mathrm{N}$; Kock 1969) and thus, the Ethiopian locality is the southernmost extension of this species' range in eastern Africa. The new Ethiopian record also originates from the highest altitude locality of $R$. microphyllum in Africa, since in other African range countries this bat occurs rather in lowlands or in the Atlas Mountains of Morocco up to $1100 \mathrm{~m}$ a. s. 1. (cf. Aulagnier and Destre 1985). On the other hand, the Ethiopian locality is still not the highest site of the whole range of this bat, since in the Middle East it has been recorded up to $1775 \mathrm{~m}$ a. s. 1. (Benda et al. 2012a).

Measurements of the collected specimen are as follows: weight $20 \mathrm{~g}$, head and body length $79 \mathrm{~mm}$, tail length $57 \mathrm{~mm}$, forearm length $69 \mathrm{~mm}$, ear length $17 \mathrm{~mm}$, tragus length $7 \mathrm{~mm}$, largest skull length $19.90 \mathrm{~mm}$, condylocanine length $17.76 \mathrm{~mm}$, zygomatic width $11.72 \mathrm{~mm}$, neurocranium width $8.47 \mathrm{~mm}$, neurocranium height $6.87 \mathrm{~mm}$, length of upper toothrow $7.11 \mathrm{~mm}$. The species identification of $R$. microphyllum was based on the above values showing large body size of the specimen as well as its relatively short tail, much shorter than the forearm (cf. Hill 1977, Van Cakenberge and De Vree 1994). The comparison of the measurements of the bat from Dire Dawa with those of other African samples of $R$. microphyllum (Kock 1969, Koopman 1975, Hill 1977, Koch-Weser 1984, Van Cakenberge and De Vree 1994, Pearch et al. 2001) show the medium-sized body of the Ethiopian specimen, comparable with bats from Egypt, Sudan and Morocco, rather smaller than bats from the Sahel, but much larger than a bat from the geographically closest population from Djibouti ( $210 \mathrm{~km}$ away), which was referred to the small-sized west-Arabian form $R$. $m$. asirensis Nader et Kock, 1983 by Pearch et al. (2001). Similarly, the results of the molecular genetic analysis positioned the Ethiopian sample of $R$. microphyllum among the samples from North Africa, Middle East and India (Fig. 2). Although the Iranian samples created a separate cluster (posterior probability 0.98 ), the node grouping all other specimens was not supported (posterior probability 0.53 ). In this analysis, a sample from south-western Saudi Arabia, from near Bishah, a site located $340 \mathrm{~km}$ from the type locality of R. m. asirensis (Al Jowa, $17^{\circ} 00^{\prime} \mathrm{N}, 43^{\circ} 3^{\prime} \mathrm{E}$; Nader and Kock 1983), also clustered with bats from the broad area from Morocco to India. Although no type locality samples were included in this genetic comparison, the results still suggest that R. microphyllum, as a species, constitutes one morphometrically diverse but phylogenetically homogenous taxon (Schlitter and Qumsiyeh 1996, Hulva et al. 2007, Levin et al. 2008), rather than a series of more separated taxa (Hill 1977, Van Cakenberge and De Vree 1994). Hence, the results of morphometric and molecular genetic analyses, though based on the examination of a single bat, together placed the newly discovered Ethiopian population within the species limits of $R$. microphyllum.

\section{Rhinopoma cystops Thomas, 1903 - Lesser mouse-tailed bat}

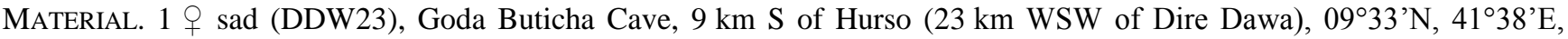
1382 m a. s. 1., 23/11/2017.

A subadult female of the lesser mouse-tailed bat was caught inside the Goda Buticha Cave in the same place as $R$. microphyllum. External measurements of the collected specimen are as follows: weight $10 \mathrm{~g}$, head and body length $67 \mathrm{~mm}$, tail length $69 \mathrm{~mm}$, forearm length $56 \mathrm{~mm}$, ear length $17 \mathrm{~mm}$, tragus length $6 \mathrm{~mm}$; skull is not available for examination. According to the body size (forearm length) and the relative long tail (longer than forearm), this specimen represents the lesser mouse-tailed bat, $R$. cystops (sensu Hulva et al. 2007). This species identification was confirmed also by molecular genetic analysis (Fig. 2).

Although $R$. cystops belongs to widespread bat species in the arid zone of the northern part of Africa (Van Cakenberge and De Vree 1994, Aulagnier 2013a), in Ethiopia this bat was documented only from few sites in a limited region of the upper part of the Awash valley at Metahara (Hill and Morris 1971, Largen et al. 1974, Demeter 1982, Benda et al. 2017). The new record from the Dire Dawa area significantly enlarges the known range of this bat species in Ethiopia and eastern Africa generally. It falls close close to the delimitation line of the south-eastern limits of the African species range, continuing eastward to northern Somalia (Van Cakenberge and De Vree 1994, Lanza et al. 2015). The new east-Ethiopian record represents also the highest African altitude recorded, since the other Ethiopian findings come from sites situated 
around $1000 \mathrm{~m}$ a. s. 1. (Hill and Morris 1971, Largen et al. 1974) and the altitude maximum known from the Algerian Sahara approaches $1200 \mathrm{~m}$ a. s. 1. only (cf. Kowalski and Rzebik-Kowalska 1991).

The size of the Dire Dawa specimen of $R$. cystops conforms to the size of the known Ethiopian bats, in which the forearm length (FA) was reported in the range of 52.9-56.6 mm (mean 55.0 mm, n=13; Hill and Morris 1971) and 54.5$57.8 \mathrm{~mm}$ (mean $56.4 \mathrm{~mm}, \mathrm{n}=3$; Benda et al. 2017), respectively. The Ethiopian samples are in size very similar to the southern Arabian samples of $R$. cystops (FA 50.5-58.9 mm, mean $54.9 \mathrm{~mm}, \mathrm{n}=52$; Benda et al. 2017), but significantly differ from the large-sized bats from Somalia (FA 59.7-67.0 mm, mean $62.9 \mathrm{~mm}, \mathrm{n}=12$; Benda et al. 2017). The results of molecular genetic comparison (Fig. 2) clustered the Dire Dawa specimen with the sequences of $R$. cystops from the Middle East (Yemen, Socotra, Jordan, Syria), creating a sister lineage to the sequences from North Africa (Egypt, Libya). The genetic similarities thus are in accordance with the morphometric findings (see also Benda et al. 2017).

Hulva et al. (2007) referred the two lineages of $R$. cystops to two subspecies, African $R$. $c$. cystops and Middle Eastern $R$. c. arabium Thomas, 1913 and the Red Sea was regarded as a border between these lineages/subspecies. However, while the Ethiopian sample belongs to the Middle Eastern lineage by our analysis, perhaps all species' populations of the Horn of Africa belong rather to $R$. c. arabium than to the nominotypical form. An alternative explanation of this result could be a mosaic-like border between the lineages, when a certain percentage of individuals of one of the bordering population bears haplotypes of the opposite populations, similarly, as it was already found in Rousettus aegyptiacus and/or Asellia tridens (Geoffroy, 1813) in the identical geographical arrangement across the Red Sea (see Benda et al. 2012b, Bray and Benda 2016).

\section{Chaerephon pumilus (Cretzschmar, 1830) - Little free-tailed bat}

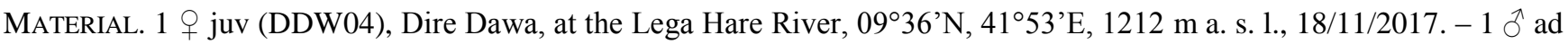
(DDW17), Dire Dawa, Toni Farm (Dire Dawa University), 09³7’N, 4150’E, 1148 m a. s. 1., 21/11/2017.

Two specimens of the little free-tailed bat were collected in agricultural areas adjacent to Dire Dawa town. This species belongs to one of the most common bats in various savannah zones of Africa (Happold 2013b); with the exceptions of true deserts and true forests, it is distributed widely across Ethiopia (Largen et al. 1974). C. pumilus was also repeatedly recorded in broader region of the eastern Chercher Mountains, viz. Haramaya, Babile, Errer valley, Harar (Largen et al. 1974, Demeter and Topál 1982, Lavrenchenko et al. 2010). Measurements of the specimens collected at Dire Dawa are as follows (DDW04/DDW17): weight 9.0/10.2 g, head and body length 87/70 mm, tail length 27/36 mm, forearm length $39 / 40 \mathrm{~mm}$, ear length $17 / 15 \mathrm{~mm}$, largest skull length $16.25 / 17.35 \mathrm{~mm}$, condylobasal length $15.18 / 16.29 \mathrm{~mm}$, zygomatic width $10.18 / 10.47 \mathrm{~mm}$, neurocranium width $8.05 / 8.15 \mathrm{~mm}$, neurocranium height 5.41/6.19 mm, length of upper tooth-row $6.31 / 6.51 \mathrm{~mm}$. These values conform to the measurement ranges known for the species (see, e.g. Lavrenchenko et al. 2004, Happold 2013b).

\section{Scotophilus leucogaster (Cretzschmar, 1830) - White-bellied house bat}

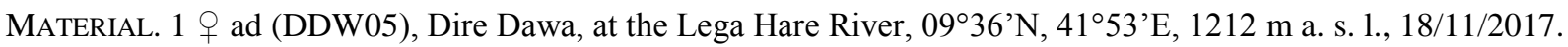

A female of the white-bellied house bat was caught in an agricultural area adjacent to Dire Dawa town. This species is rare in Ethiopia, verified records are available only from the western part of the country (Largen et al. 1974, Robbins et al. 1985). In the eastern part of the Chercher Mountains, including Dire Dawa area, only the larger and brighter species $S$. colias Thomas, 1904 has been reported (Robbins et al. 1985, sensu Vallo et al. 2011). However, the identification of the newly recorded Dire Dawa bat as S. leucogaster is clear from its rather small body and skull size fitting to the genetically identified samples by Vallo et al. (2019). Measurements of this specimen are as follows: weight $18 \mathrm{~g}$, head and body length $83 \mathrm{~mm}$, tail length $55 \mathrm{~mm}$, forearm length $50 \mathrm{~mm}$, ear length $16 \mathrm{~mm}$, tragus length $9 \mathrm{~mm}$, largest skull length $18.82 \mathrm{~mm}$, condylobasal length $17.44 \mathrm{~mm}$, zygomatic width $13.36 \mathrm{~mm}$, neurocranium width $9.31 \mathrm{~mm}$, neurocranium height $7.68 \mathrm{~mm}$, length of upper tooth-row $6.52 \mathrm{~mm}$. 
Although this new record significantly enlarges the distribution range of S. leucogaster in Ethiopia, the extent of the whole species range is not really affected; this bat is known to occur in the whole savannah belt of northern part of Africa and south-western Arabia, including most of the countries surrounding Ethiopia, like Sudan, South Sudan, Chad, Central African Republic, Kenya, Somalia or Yemen (Robbins et al. 1985, Vallo et al. 2011, Lanza et al. 2015).

Considering the measurement values given (forearm length $48.6 \mathrm{~mm}$, upper tooth-row length $6.7 \mathrm{~mm}$ ) and pale colouration description, the Scotophilus specimen collected by Lavrenchenko et al. (2010) in the Babile Elephant Sanctuary, some 80-90 km south-east of Dire Dawa, and reported as $S$. cf. dinganii (Smith, 1833), could belong to S. leucogaster. Such a record there could be regarded as more possible in light of our finding from Dire Dawa. However, the detailed skull examination and/or genetic comparison is necessary to solve the identification of the concerned bat.

\section{Conclusions}

In the Dire Dawa area, we documented the occurrence of six bat species belonging to four families and three of these species as completely new records in the broader region of the eastern Chercher Mountains, one as a new species for Ethiopia as well. The recorded bat species represent three various types concerning their biogeographic affinities. Epomophorus minimus, Chaerephon pumilus, and Scotophilus leucogaster are true Afro-tropical elements whose distribution is confined solely to savannahs of sub-Saharan Africa and (in the cases of the two latter species) to the southwestern corner of the Arabian Peninsula. On the other hand, Rhinopoma microphyllum and $R$. cystops are inhabitants of the Saharo-Sindian arid region, and their distributions are centred to deserts of the Palaearctic-Afro-tropical transition. Rousettus aegyptiacus belongs to a rare biogeographic type, being distributed broadly in the Afro-tropics, but also in the southern Palaearctic. The easternmost extent of the Chercher Mountains, including the Dire Dawa area, is a region of mixing of these two-main biogeographic elements, the Afro-tropical savannah bats and the Saharo-Sindian dry scrubland bats. While Epomophorus minimus finds in the Chercher Mountains the north-eastern limit of its whole distribution range, both Rhinopoma species find there the southern limits of their distributions in Africa.

After all, such a mixing is apparent from the whole bat faunal list of the region, now comprising 24 species, and besides Dire Dawa area, also covering Harar and Babile areas in the east, and the central Chercher Mts. in the west (Table 1). Naturally, the prevailing majority of documented species (17) represent Afro-tropical bats. Five species are representatives of mixed biogeographic affinities - they are elements occurring in both the southern Palaearctic and Afro-topical savannahs, viz. Rousettus aegyptiacus, Rhinolophus clivosus, R. blasii, Taphozous perforatus and Nycteris thebaica. The two newly documented Rhinopoma species remain the only Saharo-Sindian species of the eastern Chercher Mountains region.

To be concluded, in this contribution we extended the geographical distribution of three species towards the east of Ethiopia and provided new data on their altitudinal ranges. We again confirmed eastern Ethiopia as a biogeographical crossroad between the Afro-tropical and Palaearctic regions at various scales.

\section{Acknowledgements}

This work was funded by LABEX-BCDIV CNRS-MNHN, preparation was supported by the Ministry of Culture of the Czech Republic: project NAKI II (DG16P02B038), for PB. We acknowledge the precious help of Dr Fanuel Kebede Gorfu, Ethiopian Wildlife Research \& Monitoring in Addis Ababa. We thank the Environment, Forest, Wildlife and Climate Change Authority of the Oromia National Regional Government that provided a research permit (No. Lakk.ATENRSO/213-1585 guyyaa 4/03/2010). We also express our gratitude to East Hararge Zone and Chelenko District, Harar, and the Dire Dawa Administration Mayor Office. We thank Abdi Mohamed of the Dire Dawa Agriculture, Water, Mines and \& Energy Bureau and Dire Dawa University. In particular we thanks, Mr. Abdi Mohamed, Dr Yitiberek Getachew, and Mr. Molla Fentie of the Dire Dawa University. Khalid Naji, a biodiversity expert, Chelenko District, also assisted us for authorisations and facilitation. In the field, a special mention is to be given to the Chief and authorities of Serkama Village (Hamedin Mahmoud Hassan) as well as to our driver Motbaynor Wogayehu. In the Addis Ababa Museum, we thank Yonas Andualem, director of the cultural heritage collection and Mr. Sahle for their great support. We are grateful to Peter Taylor for attentive reading and english polishing of this manuscript correction. 


\section{References}

Akaike, H. 1973. Information theory and an extension of the maximum likelihood principle. Second International Symposium on Information Theory (ed. by C.F. Petrov B.N.), pp. 267-281. Akademiai Kiado, Budapest.

Aulagnier, S. 2013a. Rhinopoma hardwickii Lesser mouse-tailed bat. In: (M. Happold and D.C.D. Happold, eds.) Mammals of Africa. Volume IV. Hedgehogs, shrews and bats. Bloomsbury, Publishing, London, UK. pp. $412-414$.

Aulagnier, S. 2013b. Rhinopoma microphyllum Greater mouse-tailed bat. In: (M. Happold and D.C.D. Happold, eds.) Mammals of Africa. Volume IV. Hedgehogs, shrews and bats. Bloomsbury, Publishing, London, UK. pp. $415-417$.

Aulagnier, S. and R. Destre. 1985. Introduction a l'etude des chiropteres du Tafilalt (sud-est marocain). Mammalia 49: 329337.

Benda, P., K. Faizolahi, M. Andreas, J. Obuch, A. Reiter, M. Ševčík, M. Uhrin, P. Vallo and S. Ashrafi. 2012a. Bats (Mammalia: Chiroptera) of the Eastern Mediterranean and Middle East. Part 10. Bat fauna of Iran. Acta Soc. Zool. Bohem. 76: 163-582.

Benda, P., P. Vallo, P. Hulva and I. Horáček. 2012b. The Egyptian fruit bat Rousettus aegyptiacus (Chiroptera: Pteropodidae) in the Palaearctic: Geographical variation and taxonomic status. Biologia 67: 1230-1244.

Benda, P., T. Andriollo and M. Ruedi. 2015. Systematic position and taxonomy of Pipistrellus deserti (Chiroptera: Vespertilionidae). Mammalia 79: 419-438.

Benda, P., A. Reiter, M. Uhrin and Z. Varadínová. 2016. A new species of pipistrelle bat (Chiroptera: Vespertilionidae) from southern Arabia. Acta Chiropterol. 18: 301-323.

Benda, P., A.K. Nasher, K. Van Damme, P. Vallo and A. Reiter. 2017. Bats (Mammalia: Chiroptera) of the Eastern Mediterranean and Middle East. Part 14. Bats of the Socotra Archipelago, Yemen. Acta Soc. Zool. Bohem. 81: 99-169.

Bergmans, W. 1994. Taxonomy and biogeography of African fruit bats (Mammalia, Megachiroptera). 4. The genus Rousettus Gray, 1821. Beaufortia 44: 79-126.

Bray, T.C. and P. Benda. 2016. Distribution of Asellia tridens (Chiroptera: Hipposideridae) lineages including representatives from Saudi Arabia. Zool. Middle East 62: 283-287.

Claessen, C.J. and F. De Vree. 1991. Systematic and taxonomic notes on the Epomophorus anurus-labiatus-minor complex with the description of a new species (Mammalia: Chiroptera: Pteropodidae). Senckenberg. Biol. 71: $209-238$.

Demeter, A. 1982. Prey of the spotted eagle-owl Bubo africanus in the Awash National Park, Ethiopia. Bonn. Zool. Beitr. 33: 283-292.

Demeter, A. and G. Topál. 1982. Ethiopian mammals in the Hungarian Natural History Museum. Ann. Histor.-Natur. Mus. Natl. Hungar. 74: 331-349.

Ducroz, J.F., V. Volobouev and L. Granjon. 2001. An assessment of the systematics of Arvicanthine rodents using mitochondrial DNA sequences: evolutionary and biogeographical implications. J. Mammal. Evol. 8: $173-206$.

Friis, I., Sebsebe Demissew \& P. van Breugel. 2011. Atlas of the Potential Vegetation of Ethiopia. Addis Ababa University Press \& Shama Books, Addis Ababa, Ethiopia, pp. 307.

Happold, M. 2013a. Rousettus aegyptiacus Egyptian Rousette. In: (M. Happold and D.C.D. Happold, eds.) Mammals of Africa. Volume IV. Hedgehogs, shrews and bats. Bloomsbury, Publishing, London, UK. pp. $289-292$.

Happold, M. 2013b. Tadarida pumila Little free-tailed bat. In: (M. Happold and D.C.D. Happold, eds.) Mammals of Africa. Volume IV. Hedgehogs, shrews and bats. Bloomsbury, Publishing, London, UK. pp. 528-530

Hayman, R.W. and J.E. Hill. 1971. Part 2. Order Chiroptera. In: (J. Meester and H. W. Setzer, eds.) The mammals of Africa: an identification manual. Smithsonian Institution Press, Washington, DC, USA. pp. 1-73.

Hill, J.E. 1977. A review of the Rhinopomatidae (Mammalia: Chiroptera). Bull. Brit. Mus. Natur. Hist., Zool. S. $32: 29-43$.

Hill, J.E. and P. Morris. 1971. Bats from Ethiopia collected by the great Abbai Expedition 1968. Bull. Brit. Mus. Natur. Hist. (Zool.) 21: 27-49.

Hulva, P., I. Horáček and P. Benda. 2007. Molecules, morphometrics and new fossils provide an integrated view of the evolutionary history of Rhinopomatidae (Mammalia: Chiroptera). BMC Evol. Biol. 7: 165.

Koch-Weser, S. 1984. Fledermäuse as Obervolta, W-Afrika (Mammalia: Chiroptera). Senckenberg. Biol. 64: $255-311$.

Kock, D. 1969. Die Fledermaus-Fauna de Sudan (Mammalia, Chiroptera). Abh. Senckenberg. Naturforsch. Ges. 521: 1238.

Koopman, K.F. 1975. Bats of the Sudan. Bull. Am. Mus. Natur. Hist. 154: 355-443. 
Kowalski, K. and B. Rzebik-Kowalska. 1991. Mammals of Algeria. Zaklad Narodowy im. Ossolińskich, Wroclaw, Poland. pp. 371 .

Kruskop, S.V., P. Benda, D.A. Vasenkov and L.A. Lavrenchenko. 2016. First records of bats from the Alatish National Park, north-western Ethiopia (Chiroptera). Lynx, n.s. 47: 51-69.

Lanza, B., U. Funaioli and M. Riccucci. 2015. The bats of Somalia and neighbouring areas. Edition Chimaira, Frankfurt am Main, Germany, pp. 566.

Largen, M.J., D. Kock and D. Yalden. 1974. Catalogue of the mammals of Ethiopia. 1. Chiroptera. Monitore Zoologico Italiano, N.S., 16, Supplemento 5: 221-298.

Larget, B., and D. L. Simon. 1999. Markov Chain Monte Carlo Algorithms for the Bayesian Analysis of Phylogenetic Trees. Mol. Biol. Evol. 16: 750-759.

Lavrenchenko, L. and Afework Bekele. 2017. Diversity and conservation of Ethiopian mammals: what have we learned in 30 years. Ethiop. J. Biol. Sci. 16(Suppl.): 1-20.

Lavrenchenko, L.A., S.V. Kruskop and P.N. Morozov. 2004: Notes on the bats (Chiroptera) collected by the Joint Ethiopian-Russian Biological Expedition, with remarks on their systematics, distribution, and ecology. Bonn. Zool. Beitr. 52: 127-147.

Lavrenchenko, L.A., S.V. Kruskop, Afework Bekele, Gurja Belay, P.N. Morozov, Yu.F. Ivlev and A.A. Warshavsky. 2010. Mammals of the Babille Elephant Sanctuary (Eastern Ethiopia). Russ. J. Theriol. 9: 47-60.

Levin, E., Y. Yom-Tov, A. Barnea and D. Huchon. 2008. Genetic diversity and phylogeography of the greater mouse-tailed bat Rhinopoma microphyllum (Brünnich, 1782) in the Levant. Acta Chiropterol. 10: 207-212.

Memish, Z.A., N. Mishra, K.J. Olival, S.F. Fagbo, V. Kapoor, J.H. Epstein, R. Al akeem, M. Al Asmari, A. Islam, A. Kapoor, T. Briese, P. Daszak, A.A. Al Rabeeah and W.I. Lipkin. 2013. Middle East Respiratory Syndrome Coronavirus in bats, Saudi Arabia. Emerg. Infect. Dis. 19: 1819-1823.

Nader, I.A. and D. Kock. 1983. Rhinopoma microphyllum asirensis n. subsp. from southwestern Saudi Arabia (Mammalia: Chiroptera: Rhinopomatidae). Senckenberg. Biol. 63: 147-152.

Pearch, M.J., P.J.J. Bates and C. Magin. 2001. A review of the small mammal fauna of Djibouti and the results of a recent survey. Mammalia 65: 387-409.

Posada,D.\& Crandall,K.A.2001.Selecting the best-fit model of nucleotidesubstitution. Systematic Biology, 50, 580-60.

Robbins, B., F. De Vree and V. Van Cakenberghe. 1985. A systematic revision of the African bat genus Scotophilus (Vespertilionidae). Ann. Mus. Roy. Afr. Centr., Sci. Zool. 246: 53-84.

Ronquist, F. and J.P. Huelsenbeck. 2003. MrBayes 3: Bayesian phylogenetic inference under mixed models. Bioinformatics 19: 1572-1574.

Schlitter, D.A. and M.B. Qumsiyeh. 1996. Rhinopoma microphyllum. Mammal. Species 542: 1-5.

Sordelli, F. 1902. Materiali per la conoscenza della fauna Eritrea, raccolti dal dott. Paolo Magretti. Mammiferi. Atti. Soc. Ital. Sci. Natur. 41: 49-99.

Stř́́bná, T., D. Romportl, J. Demjanovič, A. Vogeler, M. Tschapka, P. Benda, I. Horáček, J. Juste, S.M. Goodman and P. Hulva. 2019. Pan-African phylogeography and paleodistribution of rousettine fruit bats: Ecogeographic correlation with Pleistocene climate-vegetation cycles. J. Biogeogr. 46: 2336-2349.

Vallo, P., P. Benda and A. Reiter. 2011. Yellow-bellied or white-bellied? Identity of Arabian house bats (Vespertilionidae: Scotophilus) revealed from mitochondrial DNA and morphology. Afr. Zool. 46: 350-361.

Vallo, P., D.M. Reeder, M.E. Vodzak and P. Benda. 2019. Resurrection of an East African house bat species, Scotophilus altilis Allen, 1914 (Chiroptera: Vespertilionidae). Zootaxa 4577: 148-160.

Van Cakenberghe, V. and F. De Vree. 1994. A revision of the Rhinopomatidae Dobson 1872, with the description of a new subspecies (Mammalia: Chiroptera). Senckenberg. Biol. 73: 1-24.

Yalden, D.W., M.J. Largen, D. Kock and J.C. Hillman. 1996. Catalogue of the mammals of Ethiopia and Eritrea. Revised checklist, zoogeography and conservation. Trop. Zool. 9: 73-164. 
Table 1. Composition of the bat faunas in several areas of the eastern edges of the Chercher Mountains (contemporary nomenclature used) and species diversity per field work.

\begin{tabular}{|c|c|c|c|c|}
\hline $\begin{array}{l}\text { Dire Dawa area, } \\
\text { this study }\end{array}$ & $\begin{array}{l}\text { Dire Dawa area, } \\
\text { Largen et al. (1974), } \\
\text { Robbins et al. (1985) }\end{array}$ & $\begin{array}{l}\text { Harar area, } \\
\text { Largen et al. (1974), } \\
\text { Robbins et al. (1985) }\end{array}$ & $\begin{array}{l}\text { Central Chercher Mts., } \\
\text { Lavrenchenko et al. } \\
(2004)\end{array}$ & $\begin{array}{l}\text { Babile Sanctuary, } \\
\text { Lavrenchenko et al. (2010) }\end{array}$ \\
\hline Rousettus aegyptiacus & & Rousettus aegyptiacus & Rousettus aegyptiacus & \\
\hline Epomophorus minimus & & Epomophorus minimus & & Epomophorus minimus \\
\hline \multicolumn{5}{|l|}{ Rhinopoma microphyllum } \\
\hline \multicolumn{5}{|l|}{ Rhinopoma cystops } \\
\hline & & & & Rhinolophus fumigatus \\
\hline & & Rhinolophus clivosus & & \\
\hline & Rhinolophus blasii & Rhinolophus blasii & & \\
\hline & Hipposideros tephrus & Hipposideros tephrus & & Hipposideros tephrus \\
\hline & Hipposideros megalotis & Hipposideros megalotis & & \\
\hline & Triaenops afer & & & \\
\hline & & & & Lavia frons \\
\hline & Taphozous perforatus & Taphozous perforatus & & \\
\hline & Nycteris thebaica & Nycteris thebaica & & Nycteris thebaica \\
\hline \multirow[t]{7}{*}{ Chaerephon pumilus } & Chaerephon pumilus & Chaerephon pumilus & & Chaerephon pumilus \\
\hline & & Chaerephon bivittatus & & \\
\hline & & & Pipistrellus hesperidus & \\
\hline & & & Pipistrellus aero & \\
\hline & Neoromicia somalica & Neoromicia somalica & & \\
\hline & & & & Neoromicia zuluensis \\
\hline & & Neoromicia nana & & \\
\hline \multirow[t]{4}{*}{ Scotophilus leucogaster } & & & & Scotophilus sp. \\
\hline & Scotophilus colias & Scotophilus colias & & \\
\hline & & Miniopterus africanus & & \\
\hline & & Miniopterus arenarius & & \\
\hline 6 & 9 & 15 & 3 & 8 \\
\hline
\end{tabular}




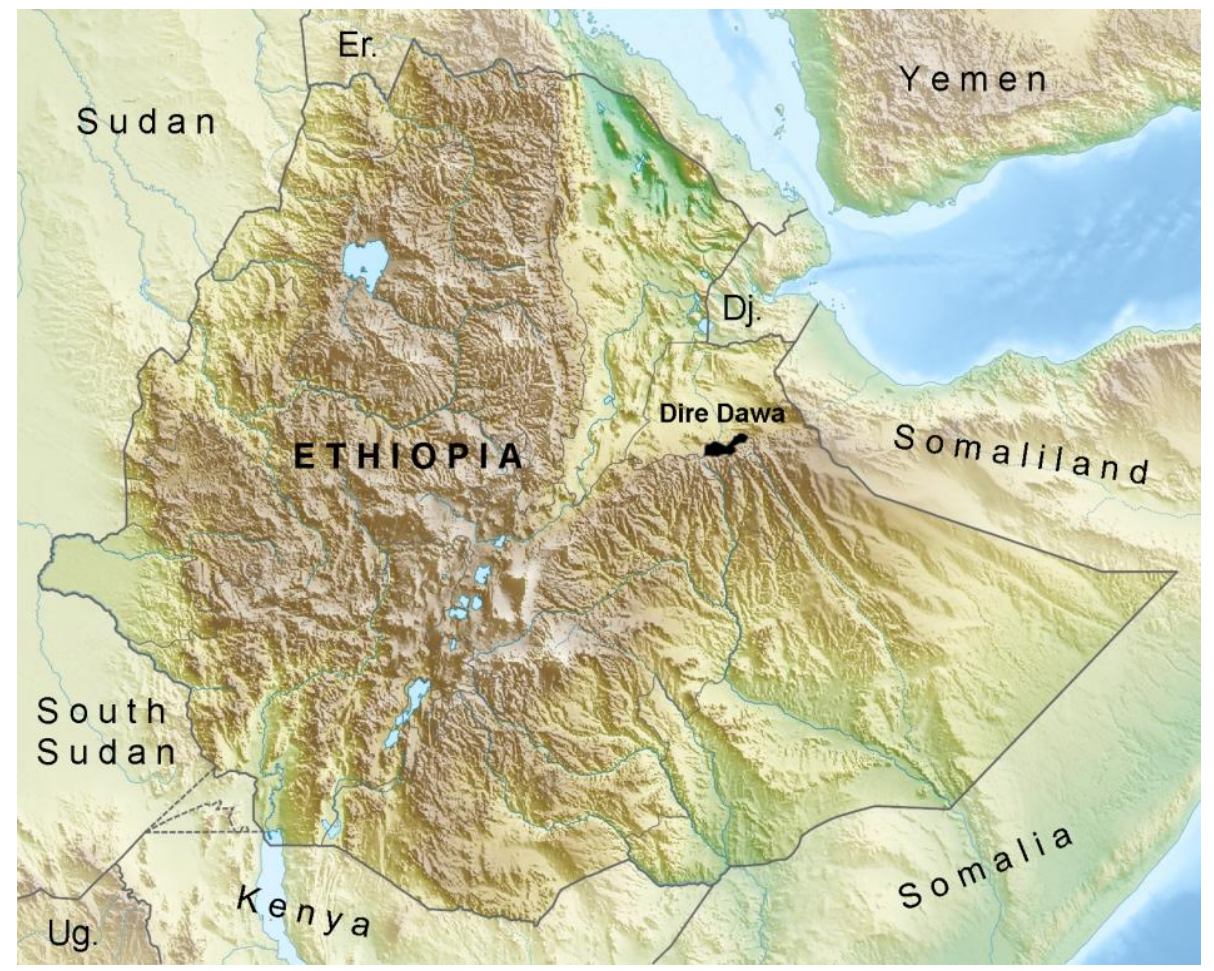

Figure 1. Localisation of the Dire Dawa Federal State (black area) in the map of Ethiopia (Er - Eritrea, Dj - Djibouti, Ug Uganda). Note the position of Dire Dawa between the Afar lowlands in the north (covered by the dry savannah) and the Chercher Mountains in the south and south-west (covered by the evergreen Afromontane forest). 
Figure 2:

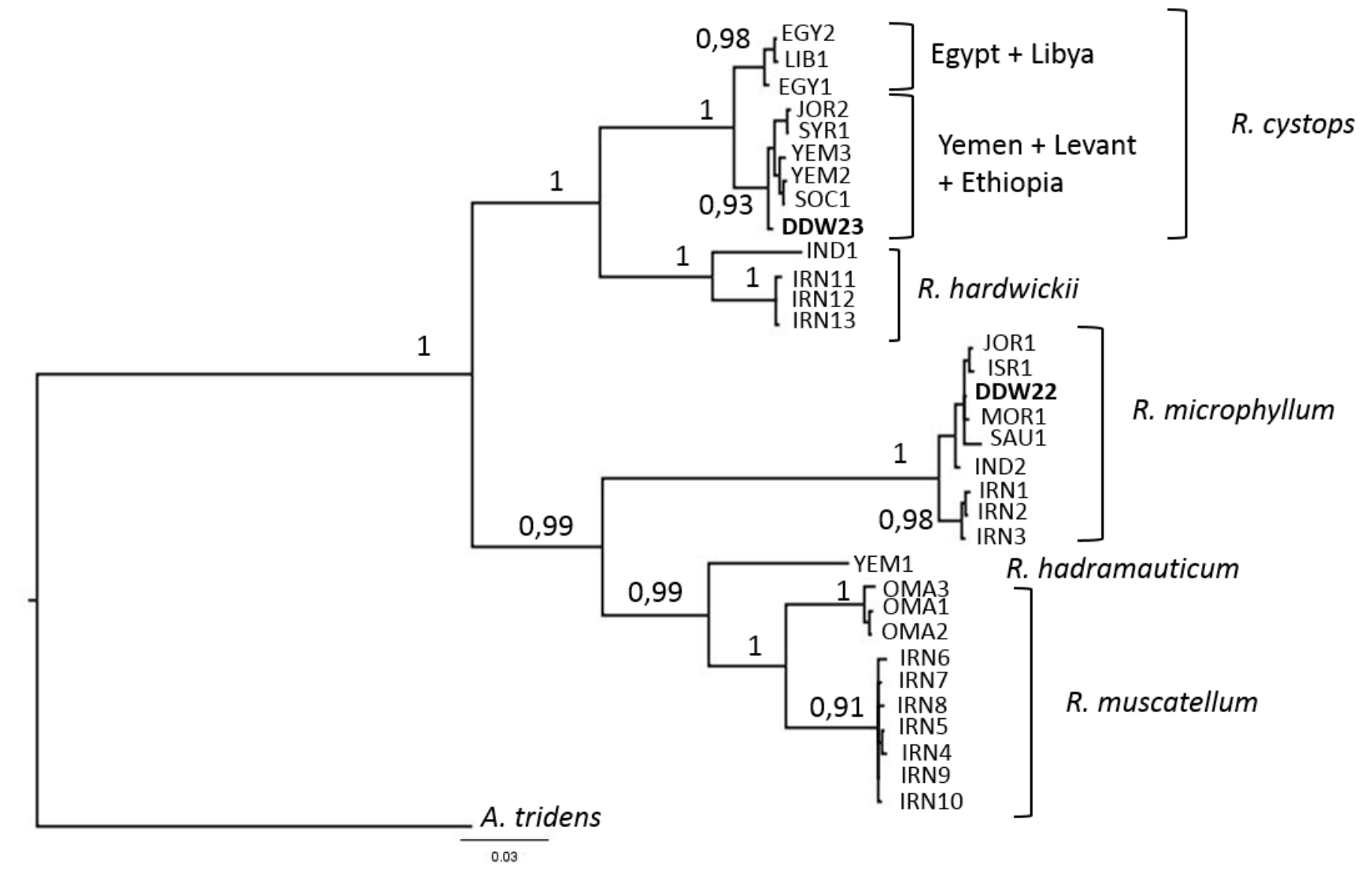

\section{Legend of the figure:}

Figure 2. Bayesian consensus tree showing position of the two Rhinopoma samples from Dire Dawa area, Ethiopia (DDW22 and DDW23) based on the cytochrome $b$ sequences. Numbers at nodes indicated posterior probabilities (only the values higher than 0.90 are presented). 


\section{Appendix}

List of sequences used in the molecular genetic comaprison of the genus Rhinopoma (Fig. 1)

\begin{tabular}{|c|c|c|c|c|c|}
\hline code tree & seqLength & GenBank & species & geographic origin & reference \\
\hline EGY2 & $1,140 \mathrm{bp}$ & KF874527 & Rhinopoma cystops & Egypt, Luxor, Karnak & Benda et al. 2012a \\
\hline EGY1 & $1,140 \mathrm{bp}$ & KF874526 & Rhinopoma cystops & Egypt, Luxor, Valley of Kings & Benda et al. 2012a \\
\hline JOR2 & $1,140 \mathrm{bp}$ & KF874528 & Rhinopoma cystops & Jordan, Wadi Shu'ayb & Benda et al. 2012a \\
\hline LIB1 & $402 \mathrm{bp}$ & DQ337491 & Rhinopoma cystops & Libya, Al Jaghbub & Hulva et al. 2007 \\
\hline SOC1 & $1,140 \mathrm{bp}$ & KF874532 & Rhinopoma cystops & Yemen, Socotra I., Wadi Darho & Benda et al. 2012a \\
\hline SYR1 & $1,140 \mathrm{bp}$ & KF874529 & Rhinopoma cystops & Syria, Qala'at Nimrod & Benda et al. 2012a \\
\hline YEM2 & $1,140 \mathrm{bp}$ & KF874531 & Rhinopoma cystops & Yemen, Am Rija & Benda et al. 2012a \\
\hline YEM3 & $1,140 \mathrm{bp}$ & KF874530 & Rhinopoma cystops & Yemen, Ma'arib & Benda et al. 2012a \\
\hline DDW23 & $1,140 \mathrm{bp}$ & MK894587 & Rhinopoma cystops & Ethiopia, Goda Buticha Cave & this study \\
\hline YEM1 & $1,140 \mathrm{bp}$ & KF874537 & Rhinopoma hadramauticum & Yemen, Ash Shahr & Benda et al. 2012a \\
\hline IND1 & $1,140 \mathrm{bp}$ & KF874522 & Rhinopoma hardwickii & India, Rajasthan, Gola-Ka-Baas & Benda et al. 2012a \\
\hline IRN11 & $1,140 \mathrm{bp}$ & KF874523 & Rhinopoma hardwickii & Iran, Sarkan & Benda et al. 2012a \\
\hline IRN12 & $1,140 \mathrm{bp}$ & KF874524 & Rhinopoma hardwickii & Iran, Sarkan & Benda et al. 2012a \\
\hline IRN13 & $1,140 \mathrm{bp}$ & KF874525 & Rhinopoma hardwickii & Iran, Mormori & Benda et al. 2012a \\
\hline IRN2 & $1,140 \mathrm{bp}$ & KF874536 & Rhinopoma microphyllum & Iran, Bishapur & Benda et al. 2012a \\
\hline IRN1 & $1,140 \mathrm{bp}$ & KF874535 & Rhinopoma microphyllum & Iran, Manian & Benda et al. 2012a \\
\hline IRN3 & $1,140 \mathrm{bp}$ & KF874534 & Rhinopoma microphyllum & Iran, Mormori & Benda et al. 2012a \\
\hline JOR1 & $1,140 \mathrm{bp}$ & KF874533 & Rhinopoma microphyllum & Jordan, Tabaqat Fahl & Benda et al. 2012a \\
\hline IND2 & $402 \mathrm{bp}$ & AM931061 & Rhinopoma microphyllum & India, New Delhi & Levin et al. 2008 \\
\hline ISR1 & $402 \mathrm{bp}$ & AM931063 & Rhinopoma microphyllum & Israel, Hula Valley & Levin et al. 2008 \\
\hline MOR1 & $402 \mathrm{bp}$ & AM931062 & Rhinopoma microphyllum & Morocco, Agadir-id-Aisha & Levin et al. 2008 \\
\hline SAU1 & $317 \mathrm{bp}$ & KF498641 & Rhinopoma microphyllum & Saudi Arabia, Old Najiah & Memish et al. 2013 \\
\hline DDW22 & $1,140 \mathrm{bp}$ & MK894586 & Rhinopoma microphyllum & Ethiopia, Goda Buticha Cave & this study \\
\hline IRN4 & $1,140 \mathrm{bp}$ & KF874544 & Rhinopoma muscatellum & Iran, Bishapur & Benda et al. 2012a \\
\hline IRN5 & $1,140 \mathrm{bp}$ & KF874545 & Rhinopoma muscatellum & Iran, Bishapur & Benda et al. 2012a \\
\hline IRN9 & $1,140 \mathrm{bp}$ & KF874546 & Rhinopoma muscatellum & Iran, Hormoz I. & Benda et al. 2012a \\
\hline IRN6 & $1,140 \mathrm{bp}$ & KF874541 & Rhinopoma muscatellum & Iran, Mach Gur & Benda et al. 2012a \\
\hline IRN10 & $1,140 \mathrm{bp}$ & KF874547 & Rhinopoma muscatellum & Iran, Pir Sohrab & Benda et al. 2012a \\
\hline IRN7 & $1,140 \mathrm{bp}$ & KF874542 & Rhinopoma muscatellum & Iran, Sarkan & Benda et al. 2012a \\
\hline IRN8 & $1,140 \mathrm{bp}$ & KF874543 & Rhinopoma muscatellum & Iran, Sarkan & Benda et al. 2012a \\
\hline OMA2 & $1,140 \mathrm{bp}$ & KF874540 & Rhinopoma muscatellum & Oman, Al Aqar & Benda et al. 2012a \\
\hline OMA1 & $1,140 \mathrm{bp}$ & KF874539 & Rhinopoma muscatellum & Oman, Al Qarbi Ash Sharqiyah & Benda et al. 2012a \\
\hline OMA3 & $1,140 \mathrm{bp}$ & KF874538 & Rhinopoma muscatellum & Oman, Muqal & Benda et al. 2012a \\
\hline
\end{tabular}

